\title{
The role of maize root size in phosphorus uptake and productivity of maize/faba bean and maize/wheat intercropping systems
}

\author{
ZHANG YiKai, CHEN FanJun, LI Long, CHEN YanHua, LIU BingRan, ZHOU YuLing, \\ YUAN LiXing, ZHANG FuSuo \& MI GuoHua*
}

\author{
Key Laboratory of Plant-Soil Interactions, Ministry of Education, Center for Resources, Environment and Food Security, \\ College of Resources and Environmental Science, China Agricultural University, Beijing 100193, China
}

Received July 14, 2012; accepted August 24, 2012; published online October 31, 2012

\begin{abstract}
Interspecific root/rhizosphere interactions affect phosphorus $(\mathrm{P})$ uptake and the productivity of maize/faba bean and maize/wheat intercropping systems. The aim of these experiments was to determine whether manipulation of maize root growth could improve the productivity of the two intercropping systems. Two near isogenic maize hybrids (the larger-rooted T149 and smaller-rooted T222) were intercropped with faba bean and wheat, under conditions of high- and low-P availability. The larger-rooted T149 showed greater competitive ability than the smaller-rooted T222 in both maize/faba bean and maize/wheat intercropping systems. The higher competitive ability of T149 improved the productivity of the maize/faba bean intercropping system in P-sufficient conditions. In maize/wheat intercropping systems, root growth, shoot biomass, and P uptake of maize were inhibited by wheat, regardless of the P-supply. Compared with T222, the larger-rooted T149 suffered less in the intercropping systems. The total biomass of the maize/wheat intercropping system was higher for wheat/T149 than for wheat/T222 under low-P conditions. These data suggested that genetic improvement of maize root size could enhance maize growth and its ability to compete for P resources in maize/faba bean and maize/wheat intercropping systems. In addition, depending on the $\mathrm{P}$ availability, larger maize roots could increase the productivity of intercropping systems.
\end{abstract}

faba bean, intercropping, maize, phosphorus uptake, root growth, wheat

Citation: Zhang Y K, Chen F J, Li L, et al. The role of maize root size in phosphorus uptake and productivity of maize/faba bean and maize/wheat intercropping systems. Sci China Life Sci, 2012, 55: 993-1001, doi: 10.1007/s11427-012-4396-6

Phosphorus $(\mathrm{P})$ is an essential macronutrient required for plant growth, but it is the least available nutrient in most soils [1]. Approximately $30 \%-40 \%$ of terrestrial soils have insufficient available $\mathrm{P}$ for optimum crop production $[2,3]$. Roots play an important role in $\mathrm{P}$ acquisition from soils. Root morphological parameters, such as root length, number of lateral roots, and root surface area are strongly related to $\mathrm{P}$ uptake by plants, particularly when the soil $\mathrm{P}$ availability is low [4-7]. The efficiency of $P$ acquisition can also be improved by increasing $\mathrm{P}$ availability in the rhizosphere via root exudates such as protons, carboxylates, and the activi-

*Corresponding author (email: miguohua@cau.edu.cn) ties of colonizing microbes, for example, those in a mycorrhizal symbiosis $[8,9]$.

Intercropping is a multiple cropping system with two or more crops grown simultaneously in the same field [10]. This cultivation method is common in many developing countries because it allows effective use of resources such as water, light, and nutrients [11-13]. In China, more than 28 million $\mathrm{hm}^{2}$ of annually sown areas are under intercropping [14]. Maize/faba bean and maize/wheat intercropping systems have a long history in northwestern China where the annual temperature does not allow the planting of two sequential crops [15]. In Gansu Province, for example, the sown area of maize/wheat intercropping is $75000 \mathrm{hm}^{2}$ and 
produces a combined yield exceeding $12000 \mathrm{~kg} \mathrm{hm}^{-2}$ [12].

In maize/faba bean (legume-cereal) intercropping systems, both crops show higher $\mathrm{P}$ accumulation and biomass yields than they do in a monocropping system [12,16]. Li et al. [14] showed that yields of intercropped maize and faba bean increased by $43 \%$ and $26 \%$, respectively, compared with their yields in a monocropping system. Thus, maize/ faba bean intercropping shows symmetric interspecific facilitation [17]. Consistent with the results of Dauro and Mohamed-Saleem [18], who reported that root, but not shoot, interactions significantly affected the yields in a wheat/clover intercropping system, the increase in maize production with intercropped faba bean is largely explained by belowground interactions [19,20]. First, faba bean and maize use different $\mathrm{P}$ pools. This reduces competition between them, because faba bean has a strong capability for rhizosphere acidification [14]. Second, the root growth of faba bean and maize is compatible; faba bean has a relatively shallow root distribution, whereas intercropped maize roots extend below the faba bean root system and occupy a greater soil volume [17]. It was believed that depletion of $\mathrm{P}$ by maize roots could promote faba bean roots to release more organic acids and protons so as to increase total $\mathrm{P}$ uptake $[19,20]$.

Plant growth also may be affected negatively by intercropping. In maize/wheat (cereal-cereal) intercropping systems, maize growth is reduced because of the greater belowground competitive ability of intercropped wheat [15,21,22]. Li et al. [17] found that intercropped wheat had a larger root-length density and occupied a greater soil volume than monocropped wheat. In addition, in the intercropping system, the wheat roots extended below the maize root system. As a result, maize roots were restricted laterally to approximately $20 \mathrm{~cm}$, whereas roots of monocropped maize extended laterally approximately $40 \mathrm{~cm}$. Competitive interactions resulted in shorter, thicker maize roots with decreased nutrient absorption ability [22]. Li [23] showed that allelochemicals in wheat root exudates, such as DIMBOA, MBOA, and phenolic acids may have important effects during interspecific interactions, inhibiting the growth of maize roots.

Genotypes may also affect crop growth in an intercropping system. In a wheat and chickpea intercropping system, the P uptake of the wheat cultivar Janz was greater than that in a monocropping system, whereas the $\mathrm{P}$ uptake of the wheat cultivar Goldmark was not affected [24]. The mechanism underlying this phenomenon remains unclear.

The underground root/rhizosphere interaction plays an essential role in $\mathrm{P}$ uptake and biomass production in intercropping systems [14,22]. Changes in root traits of one crop may affect the other crop in an intercropping system, thereby affecting the productivity of the whole system. In the present study, we developed a root-specific near-isogenic line (NIL) maize population using two parents, Ye478 (larger roots) and Wu312 (smaller roots) [25]. By crossing the NILs with the same tester inbred line, 178, a total of 220 testcrosses were obtained, from which testcrosses T149 and T222 were identified as having different root sizes but similar shoot growth. T149 was more P-efficient than T222 in P-deficient calcareous soil [26]. Using these two maize genotypes with different root sizes, we evaluated the role of maize root growth in $\mathrm{P}$ uptake and productivity of maize/faba bean and maize/wheat intercropping systems.

\section{Materials and methods}

\subsection{Plant materials and growth conditions}

Generation of the isogenic maize hybrids T149 and T222 has been described previously [26]. Briefly, a $\mathrm{BC}_{4} \mathrm{~F}_{3}$ backcross population consisting of 220 lines was developed from the larger-rooted inbred Ye478 (donor parent) and the smaller-rooted inbred Wu312 (recurrent parent). The lines were crossed with inbred 178 as the male parent to generate 220 testcrosses, which included T149 and T222. Their female parents, L149 and L222, respectively, were theoretically $96.88 \%$ isogenic to Wu312. L149 harbors two quantitative trait loci for lateral root length and grain yield at chromosome bin 1.03/1.04 (umc1403/umc2112, unpublished data). While L222 does not have these loci, was used as the control. Compared with T222, T149 has a longer root length per plant and is P-efficient when grown in P-deficient calcareous soil [26].

\subsection{Experiment 1: maize/faba bean intercropping}

Seeds of maize (Zea mays L. cv. T149 and T222) and faba bean (Vicia faba L. cv. Lincan No. 5) were surface-sterilized with $10 \%(\mathrm{v} / \mathrm{v}) \mathrm{H}_{2} \mathrm{O}_{2}$ for $30 \mathrm{~min}$ and soaked for $8 \mathrm{~h}$ in a saturated $\mathrm{CaSO}_{4}$ solution. The seeds were germinated on moist filter paper at $28^{\circ} \mathrm{C}$ in the dark for $3 \mathrm{~d}$. When the roots were approximately $1 \mathrm{~cm}$ long, three germinated maize seeds or faba bean seeds were sown on one side of the pot that was virtually divided into two parts. One week after emergence, both maize and faba bean seedlings were thinned as required. Plants were grown in porcelain pots (24 cm in diameter $\times 27 \mathrm{~cm}$ in height) filled with $8 \mathrm{~kg}$ soil. There were three cropping treatments: (i) monocropping of maize (two plants per pot); (ii) monocropping of faba bean (two plants per pot); and (iii) intercropping of maize and faba bean (one plant of maize and one plant of faba bean per pot) $[27,28]$.

The low-P calcareous soil was collected from the field (0-40 cm in depth) at the Changping Long-term Fertilizer Experiment Station of China Agricultural University in Beijing, northern China $\left(40.22^{\circ} \mathrm{N}, 116.20^{\circ} \mathrm{E}\right)$. The air-dried soil was sieved (2-mm mesh size) and then thoroughly mixed with river sand (washed with tap water) (soil: sand $3: 1, \mathrm{v} / \mathrm{v}$ ) to enable easy sampling of roots. The chemical properties of 
the final soil were as follows: $\mathrm{pH} 8.33$, organic matter 7.39 $\mathrm{g} \mathrm{kg}^{-1}$, total $\mathrm{N} 0.39 \mathrm{~g} \mathrm{~kg}^{-1}$, total $\mathrm{P} 0.37 \mathrm{~g} \mathrm{~kg}^{-1}$, Olsen-P 3.18 $\mathrm{mg} \mathrm{kg}{ }^{-1}$, and $\mathrm{NH}_{4} \mathrm{OAc}-\mathrm{K} 58.06 \mathrm{mg} \mathrm{kg}^{-1}$. Phosphorus fertilizer was added as $\mathrm{KH}_{2} \mathrm{PO}_{4}$ at a rate of $20 \mathrm{mg} \mathrm{P} \mathrm{kg}^{-1}$ soil (low $\mathrm{P}$ ) or $150 \mathrm{mg} \mathrm{P} \mathrm{kg}^{-1}$ soil (high P). Other nutrients were supplied at the following rates ( $\mathrm{mg} \mathrm{kg}^{-1}$ soil): $200 \mathrm{~N}$ (as urea), $50 \mathrm{Mg}$ (as $\mathrm{MgSO}_{4}$ ), $5 \mathrm{Zn}$ (as $\mathrm{ZnSO}_{4}$ ), $5 \mathrm{Cu}$ (as $\mathrm{CuSO}_{4}$ ), 5.5 $\mathrm{Fe}$ (as EDTA-Fe), $5 \mathrm{Mn}$ (as $\mathrm{MnSO}_{4}$ ), $0.67 \mathrm{~B}\left(\right.$ as $\mathrm{H}_{3} \mathrm{BO}_{3}$ ), and $0.122 \mathrm{Mo}$ (as $\left.\left(\mathrm{NH}_{4}\right)_{6} \mathrm{Mo}_{7} \mathrm{O}_{24}\right)$. In all treatments, the soil $\mathrm{K}$ level was adjusted to be $250 \mathrm{mg} \mathrm{kg}^{-1}$ by using with $\mathrm{KCl}$. There were four replicate pots for each treatment. The pots were arranged randomly in a glasshouse and were repositioned every week. Plants were watered with distilled water to maintain $60 \%-70 \%$ of field capacity. The experiment was conducted under natural light with a daytime temperature of $20-26^{\circ} \mathrm{C}$ and a night temperature of $15-18^{\circ} \mathrm{C}$. Plants were harvested $50 \mathrm{~d}$ after emergence.

\subsection{Experiment 2: maize/wheat intercropping}

Seeds of maize (T149 and T222) and spring wheat (Triticum aestivum L. cv. Yongliang No. 4) were treated and germinated similarly as described in Experiment 1. The growth conditions and $\mathrm{P}$ treatments were the same as in Experiment 1. Three cropping treatments were applied: (i) monocropping of maize (two plants per pot); (ii) monocropping of wheat (20 plants per pot); and (iii) intercropping of maize and wheat (one plant of maize and 10 plants of wheat per pot) [23]. The experiment was conducted under natural light with a daytime temperature of $25-32^{\circ} \mathrm{C}$ and a night temperature of $18-22^{\circ} \mathrm{C}$. Plants were harvested $35 \mathrm{~d}$ after emergence.

\subsection{Plant sampling and analysis}

At harvest, shoots were cut at the soil surface and washed with deionized water. The shoots were dried at $70^{\circ} \mathrm{C}$ for $4 \mathrm{~d}$ and weighed. Oven-dried shoots were ashed at $495^{\circ} \mathrm{C}$ for $10 \mathrm{~h}$ in a muffle furnace. The ash was dissolved in $4 \mathrm{~mL}$ $\mathrm{HCl}(1: 1, \mathrm{v} / \mathrm{v})$ and the $\mathrm{P}$ concentration determined by spectrophotometric analysis [29].

Roots were carefully washed and then scanned with an Epson V700 scanner (Epson, China). During scanning, roots were placed in a glass dish containing water to untangle the roots and minimize root overlap. Large root systems were divided into several root subsamples for adequate scanning. Root length and root surface area were quantified from digital images using WinRHIZO version 5.0a (Regent Instruments, Quebec, Canada). Scanned roots were dried and weighed.

\subsection{Nutrient competitive ratio}

The competitive ratio (CR) was used to evaluate the competitive ability between different species. It provides a measure of competition in nutrient uptake by one species in intercropping over the other [28,30,31]. The CR of crop ' $a$ ' to crop ' $b$ ' in an intercropping system was calculated as follows:

$$
\mathrm{CR}_{\mathrm{ab}}=\left(\mathrm{PU}_{\mathrm{ia}} / \mathrm{PU}_{\mathrm{sa}}\right) \times \mathrm{F}_{\mathrm{a}} /\left(\mathrm{PU}_{\mathrm{ib}} / \mathrm{PU}_{\mathrm{sb}}\right) \times \mathrm{F}_{\mathrm{b}},
$$

where $\mathrm{PU}_{\mathrm{ia}}$ and $\mathrm{PU}_{\mathrm{ib}}$ are nutrient uptake by species ' $\mathrm{a}$ ' and ' $\mathrm{b}$ ' in the intercropping system, $\mathrm{PU}_{\mathrm{sa}}$ and $\mathrm{PU}_{\mathrm{sb}}$ are nutrient uptake by species ' $a$ ' and ' $b$ ' in a monocropping system, and $F_{a}$ and $F_{b}$ are the proportion of the area occupied by the crops in the intercropping system. In the present pot experiment, the proportion of the area occupied by maize and faba bean or wheat was calculated as $1: 1$. If the value of $\mathrm{CR}_{\mathrm{a}}$ is greater than 1 , the competitive ability to take up nutrients is greater for crop ' $a$ ' than for crop ' $b$ '.

\subsection{Statistics}

Data were analyzed by three-way or two-way ANOVA with a general linear model using SAS version 9.1 (SAS Institute, Cary, NC, USA). Means are presented with standard errors to indicate variation. The significance of differences between means was determined by $t$-tests $(P \leqslant 0.05)$.

\section{Results}

\subsection{Root growth in the maize/faba bean and maize/ wheat intercropping systems}

Total root length, root surface area, and root biomass of monocropped maize T149 were significantly greater than those of T222 at both P levels (Tables 1 and 2), which suggested that the root growth of T149 was genetically superior to that of T222. In the maize/faba bean intercropping system, root growth of maize was significantly affected. Compared with monocropped maize, root growth of maize intercropped with faba bean was significantly increased. Total root length, root surface area, and root biomass were increased by $48 \%, 62 \%$, and $15 \%$, respectively, in T149, and by $42 \%, 51 \%$, and $4 \%$, respectively, in T222. Compared with the monocropping system, root growth of faba bean was not significantly affected by intercropping with maize T149, but was significantly enhanced by intercropping with T222. Total root length, root surface area, and root biomass of faba bean intercropped with maize T222 increased by $39 \%, 36 \%$, and $35 \%$, respectively (Table 2 ).

Root growth of maize was inhibited when it was intercropped with wheat (Tables 3 and 4). Compared with the monocropping system, total root length, root surface area, and root biomass of maize intercropped with wheat were inhibited by $42 \%, 33 \%$, and $22 \%$, respectively, in T222, and by $37 \%, 27 \%$, and $13 \%$, respectively, in T149. Therefore, root growth in T149 was less sensitive to intercropping inhibition. At the high-P level, root growth of wheat was 
Table 1 Variance analysis of root length, root surface area, root dry weight, P concentration, P content, and shoot dry weight in the maize/faba bean intercropping system ${ }^{\text {a) }}$

\begin{tabular}{|c|c|c|c|c|c|c|c|}
\hline Crop & Sources of variation & Root length & Root surface areas & Root dry weight & $\mathrm{P}$ concentration & $\mathrm{P}$ content & Shoot dry weight \\
\hline \multirow{7}{*}{ Maize } & Genotype (G) & $79.49^{* * * *}$ & $36.19^{* * * *}$ & $98.38^{* * * *}$ & $0.01^{\mathrm{NS}}$ & $31.57^{* * * *}$ & $41.94^{* * * *}$ \\
\hline & cropping system (C) & $77.49^{* * * *}$ & $80.78^{* * * *}$ & $8.71^{* *}$ & $6.19^{*}$ & $10.97^{* * *}$ & $27.81^{* * * *}$ \\
\hline & $\mathrm{P}$ treatment $(\mathrm{P})$ & $150.45^{* * * *}$ & $60.80^{* * * *}$ & $223.32^{* * *}$ & $20.20^{* * * *}$ & $306.83^{* * *}$ & $238.04^{* * * *}$ \\
\hline & $\mathrm{G} \times \mathrm{C}$ & $4.85^{*}$ & $2.95^{\mathrm{NS}}$ & $2.59^{\mathrm{NS}}$ & $0.02^{\mathrm{NS}}$ & $13.02^{* *}$ & $19.30^{* * *}$ \\
\hline & $\mathrm{G} \times \mathrm{P}$ & $16.28^{* * *}$ & $1.09^{\mathrm{NS}}$ & $28.34^{* * *}$ & $0.94^{\mathrm{NS}}$ & $0.88^{\mathrm{NS}}$ & $2.25^{\mathrm{NS}}$ \\
\hline & $\mathrm{C} \times \mathrm{P}$ & $11.16^{* *}$ & $0.02^{\mathrm{NS}}$ & $7.62^{*}$ & $0.33^{\mathrm{NS}}$ & $22.25^{* * *}$ & $34.75^{* * *}$ \\
\hline & $\mathrm{G} \times \mathrm{C} \times \mathrm{P}$ & $1.19^{\mathrm{NS}}$ & $0.58^{\mathrm{NS}}$ & $0.28^{\mathrm{NS}}$ & $0.66^{\mathrm{NS}}$ & $2.06^{\mathrm{NS}}$ & $4.37^{*}$ \\
\hline \multirow{3}{*}{ Faba bean } & cropping system (C) & $9.24^{* *}$ & $5.37^{*}$ & $8.05^{* *}$ & $0.02^{\mathrm{NS}}$ & $25.18^{* * * *}$ & $35.71^{* * * *}$ \\
\hline & $\mathrm{P}$ treatment $(\mathrm{P})$ & $3.74^{\mathrm{NS}}$ & $5.23^{*}$ & $4.54^{*}$ & $23.57^{* * *}$ & $212.14^{* * *}$ & $49.32^{* * *}$ \\
\hline & $\mathrm{C} \times \mathrm{P}$ & $0.39^{\mathrm{NS}}$ & $0.03^{\mathrm{NS}}$ & $0.05^{\mathrm{NS}}$ & $0.38^{\mathrm{NS}}$ & $4.08^{*}$ & $0.12^{\mathrm{NS}}$ \\
\hline
\end{tabular}

a) *, Significant at the $P \leqslant 0.05$ level; **, significant at the $P \leqslant 0.01$ level; ***, significant at the $P \leqslant 0.001$ level. NS, not significant.

Table 2 Root morphology of maize and faba bean under different phosphorus supplies in the maize/faba bean intercropping system ${ }^{\text {a) }}$

\begin{tabular}{|c|c|c|c|c|c|c|c|c|}
\hline \multirow{2}{*}{\multicolumn{2}{|c|}{ Cropping system }} & \multirow{2}{*}{ Treatment } & \multicolumn{2}{|c|}{ Root length $\left(\mathrm{m} \mathrm{pot}^{-1}\right)$} & \multicolumn{2}{|c|}{ Root surface area $\left(\times 10^{-2} \mathrm{~m}^{2} \operatorname{pot}^{-1}\right)$} & \multicolumn{2}{|c|}{ Root dry weight $\left(\mathrm{g} \mathrm{pot}^{-1}\right)$} \\
\hline & & & 20 & 150 & 20 & 150 & 20 & 150 \\
\hline \multirow{5}{*}{ Maize } & \multirow{2}{*}{ Mono } & $\mathrm{T} 222$ & $58.58 \pm 1.46 \mathrm{c}$ & $86.94 \pm 13.23 c$ & $6.00 \pm 0.16 c$ & $9.19 \pm 0.65 c$ & $0.55 \pm 0.01 \mathrm{c}$ & $0.74 \pm 0.03 c$ \\
\hline & & T149 & $76.45 \pm 2.12 b$ & $132.71 \pm 5.83 b$ & $7.30 \pm 0.15 c$ & $12.36 \pm 0.76 b$ & $0.62 \pm 0.02 b$ & $1.19 \pm 0.09 \mathrm{~b}$ \\
\hline & \multirow{2}{*}{ Inter } & $\mathrm{T} 222$ & $79.21 \pm 1.96 b$ & $128.88 \pm 9.78 b$ & $9.46 \pm 1.21 b$ & $13.29 \pm 1.19 b$ & $0.48 \pm 0.02 \mathrm{~d}$ & $0.89 \pm 0.02 \mathrm{c}$ \\
\hline & & T149 & $107.61 \pm 6.19 \mathrm{a}$ & $205.90 \pm 2.40 \mathrm{a}$ & $13.33 \pm 0.50 \mathrm{a}$ & $17.46 \pm 0.37 \mathrm{a}$ & $0.70 \pm 0.02 \mathrm{a}$ & $1.40 \pm 0.07 \mathrm{a}$ \\
\hline & $\begin{array}{l}\text { Increase by } \\
\text { intercropping }(\%)\end{array}$ & $\mathrm{T} 222$ & 35.21 & 48.24 & 57.66 & 44.61 & -12.72 & 20.27 \\
\hline \multirow{5}{*}{ Faba bean } & Mono & $\mathrm{F}$ & $62.78 \pm 2.68 \mathrm{a}$ & $76.39 \pm 3.39 b$ & $8.09 \pm 0.45 \mathrm{a}$ & $9.93 \pm 0.53 b$ & $0.58 \pm 0.01 \mathrm{~b}$ & $0.68 \pm 0.02 b$ \\
\hline & \multirow{2}{*}{ Inter } & F/T222 & $88.81 \pm 8.39 \mathrm{a}$ & $103.80 \pm 4.82 \mathrm{a}$ & $11.39 \pm 0.94 \mathrm{a}$ & $12.98 \pm 1.07 \mathrm{a}$ & $0.79 \pm 0.07 \mathrm{a}$ & $0.91 \pm 0.06 \mathrm{a}$ \\
\hline & & F/T149 & $70.39 \pm 11.24 \mathrm{a}$ & $74.21 \pm 6.49 \mathrm{~b}$ & $9.04 \pm 1.52 \mathrm{a}$ & $11.13 \pm 1.00 \mathrm{ab}$ & $0.61 \pm 0.09 \mathrm{ab}$ & $0.70 \pm 0.07 b$ \\
\hline & \multirow{2}{*}{$\begin{array}{l}\text { Increase by } \\
\text { intercropping }(\%)\end{array}$} & $\mathrm{T} 222$ & 41.46 & 35.88 & 40.79 & 30.71 & 36.2 & 33.82 \\
\hline & & T149 & 12.12 & -2.85 & 11.74 & 12.08 & 5.17 & 2.94 \\
\hline
\end{tabular}

a) Values are mean \pm SE of four replicates. Different letters indicate significant difference between genotypes within the same $P$ level $(P \leqslant 0.05)$.

Table 3 Variance analysis of root length, root surface area, root dry weight, $\mathrm{P}$ concentration, $\mathrm{P}$ content, and shoot dry weight in the maize/wheat intercropping system ${ }^{\text {a) }}$

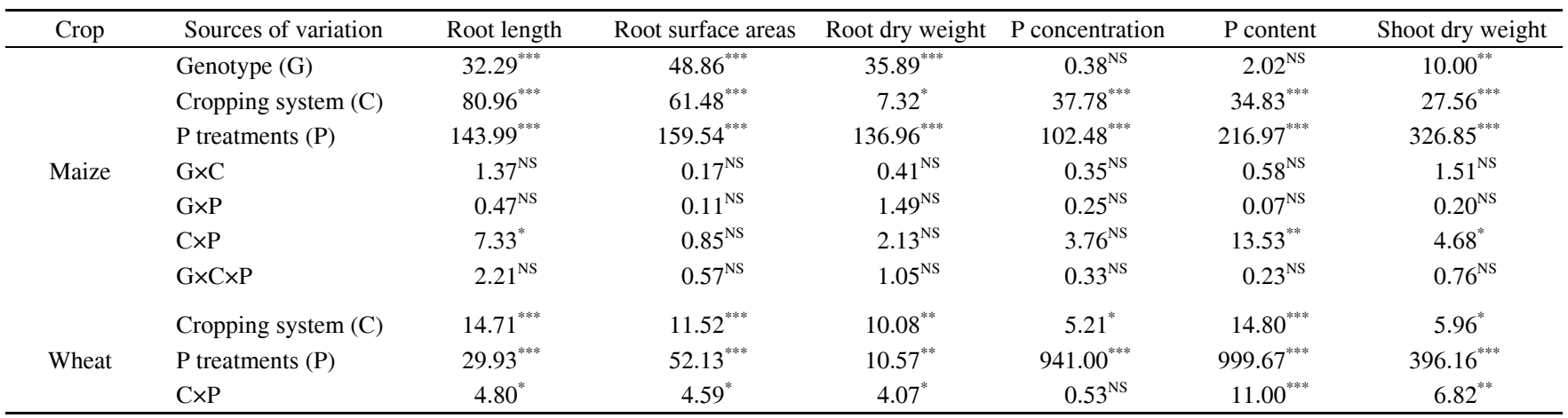

a) *, Significant at the $P \leqslant 0.05$ level; **, significant at the $P \leqslant 0.01$ level; ***, significant at the $P \leqslant 0.001$ level. NS, not significant.

enhanced by intercropping with maize. Root length, root surface area, and root biomass of wheat were significantly increased by $46 \%, 33 \%$, and $25 \%$, respectively, when intercropped with maize T222, and by $55 \%, 43 \%$, and $37 \%$, respectively, when intercropped with maize T149. At the low-P supply, wheat root growth was not significantly affected by intercropping with maize (Table 4).

\subsection{Uptake of $P$ in the maize/faba bean and maize/wheat intercropping systems}

There was no significant difference in shoot $\mathrm{P}$ concentration between T149 and T222 at all P levels. When intercropped with faba bean, the maize shoot $\mathrm{P}$ concentration decreased by $7 \%$ at low $\mathrm{P}$ and $10 \%$ at high P. In contrast, intercrop- 
ping with maize had no significant effect on the shoot $\mathrm{P}$ concentration of faba bean (Tables 1 and 5). In the monocropping system, $\mathrm{P}$ accumulation in the shoot was greater in T149 than in T222 under low-P stress, but not at the high-P level. When maize was intercropped with faba bean under low-P stress, $\mathrm{P}$ accumulation decreased by $29 \%$ in T222 but increased by $5 \%$ in T149. When P supply was sufficient, intercropping significantly increased the shoot $\mathrm{P}$ content of both maize genotypes (by $12 \%$ in T222 and by $48 \%$ in T149). Compared with monocropping, the $\mathrm{P}$ content of faba bean was increased by $37 \%$ by intercropping with T222 and by $14 \%$ by intercropping with T149 (Table 5). Therefore, faba bean derived greater benefit from intercropping with the smaller-rooted T222 than with the larger-rooted T149.

When intercropped with wheat, the shoot $\mathrm{P}$ concentration of maize was decreased by $15 \%$ and $21 \%$ across the two genotypes at low and high $\mathrm{P}$, respectively. In contrast, the shoot $\mathrm{P}$ concentration of wheat was increased by intercropping with maize by $9 \%$ under low-P supply and by $6 \%$ under high-P supply (Tables 3 and 6). Accumulation of $\mathrm{P}$ was decreased by $49 \%$ in T222 and by $33 \%$ in T149 when intercropped with wheat. In contrast, $\mathrm{P}$ accumulation in wheat significantly increased under intercropping with maize (by $8 \%$ at low-P supply and by $31 \%$ at high-P supply; Table 6).

\subsection{Biomass production in maize/faba bean and maize/ wheat intercropping systems}

In the monocropping system, there was no difference in shoot biomass between T149 and T222 when the P supply was sufficient. However, the shoot biomass of T149 was higher than that of T222 at the low-P level (Table 5). Under low $\mathrm{P}$, the shoot biomass of T222 was decreased by $21 \%$ by intercropping with faba bean, whereas that of T149 increased by $10 \%$ by intercropping with faba bean. When P supply was sufficient, intercropping with faba bean resulted in a dramatic increase in shoot biomass of T222 (by 20\%) and T149 (by 70\%). The shoot biomass of faba bean was increased by intercropping with both maize genotypes. The increase in faba bean shoot biomass was greater when it was

Table 4 Root morphology of maize and wheat under different phosphorus supply conditions in the maize/wheat intercropping system ${ }^{\text {a) }}$

\begin{tabular}{|c|c|c|c|c|c|c|c|c|}
\hline \multirow{2}{*}{\multicolumn{2}{|c|}{ Cropping system }} & \multirow{2}{*}{ Treatment } & \multicolumn{2}{|c|}{ Root length $\left(\mathrm{m} \mathrm{pot}^{-1}\right)$} & \multicolumn{2}{|c|}{ Root surface area $\left(\times 10^{-2} \mathrm{~m}^{2} \operatorname{pot}^{-1}\right)$} & \multicolumn{2}{|c|}{ Root dry weight $\left(\mathrm{g} \mathrm{pot}^{-1}\right)$} \\
\hline & & & 20 & 150 & 20 & 150 & 20 & 150 \\
\hline \multirow{5}{*}{ Maize } & \multirow{2}{*}{ Mono } & $\mathrm{T} 222$ & $29.95 \pm 1.20 \mathrm{~b}$ & $58.23 \pm 3.36 b$ & $2.79 \pm 0.12 b$ & $4.78 \pm 0.20 b$ & $0.20 \pm 0.01 b$ & $0.37 \pm 0.01 b c$ \\
\hline & & T149 & $42.26 \pm 4.15 \mathrm{a}$ & $73.81 \pm 4.20 \mathrm{a}$ & $3.80 \pm 0.27 \mathrm{a}$ & $6.14 \pm 0.22 \mathrm{a}$ & $0.29 \pm 0.03 \mathrm{a}$ & $0.46 \pm 0.03 \mathrm{ab}$ \\
\hline & \multirow{2}{*}{ Inter } & $\mathrm{T} 222$ & $16.52 \pm 2.69 \mathrm{c}$ & $39.84 \pm 0.84 \mathrm{c}$ & $1.64 \pm 0.22 c$ & $3.57 \pm 0.12 \mathrm{c}$ & $0.14 \pm 0.02 c$ & $0.32 \pm 0.01 \mathrm{c}$ \\
\hline & & T149 & $30.12 \pm 2.98 b$ & $44.59 \pm 1.24 \mathrm{c}$ & $2.75 \pm 0.26 b$ & $4.56 \pm 0.33 b$ & $0.21 \pm 0.02 b$ & $0.47 \pm 0.04 \mathrm{a}$ \\
\hline & $\begin{array}{l}\text { Increase by } \\
\text { intercropping (\%) }\end{array}$ & $\mathrm{T} 222$ & -44.84 & -31.58 & -41.21 & -25.31 & -30 & -13.51 \\
\hline \multirow{5}{*}{ Wheat } & Mono & W & $237.1 \pm 12.1 \mathrm{a}$ & $253.9 \pm 21.7 b$ & $13.05 \pm 0.60 \mathrm{a}$ & $15.21 \pm 1.06 \mathrm{~b}$ & $0.61 \pm 0.01 \mathrm{a}$ & $0.59 \pm 0.03 b$ \\
\hline & \multirow{2}{*}{ Inter } & $\mathrm{W} / \mathrm{T} 222$ & $271.3 \pm 18.9 \mathrm{a}$ & $370.4 \pm 14.5 \mathrm{a}$ & $14.11 \pm 0.99 \mathrm{a}$ & $20.22 \pm 0.78 \mathrm{a}$ & $0.64 \pm 0.04 a$ & $0.74 \pm 0.02 \mathrm{a}$ \\
\hline & & W/T149 & $273.9 \pm 20.3 \mathrm{a}$ & $393.6 \pm 16.0 \mathrm{a}$ & $14.56 \pm 0.99 \mathrm{a}$ & $21.75 \pm 0.82 \mathrm{a}$ & $0.65 \pm 0.04 \mathrm{a}$ & $0.81 \pm 0.03 \mathrm{a}$ \\
\hline & \multirow{2}{*}{$\begin{array}{l}\text { Increase by } \\
\text { intercropping }(\%)\end{array}$} & $\mathrm{T} 222$ & 14.42 & 45.88 & 8.12 & 32.93 & 4.91 & 25.42 \\
\hline & & T149 & 15.52 & 55.02 & 11.57 & 42.99 & 6.55 & 37.28 \\
\hline
\end{tabular}

a) Values are mean \pm SE of four replicates. Different letters indicate significant difference between genotypes within the same $P$ level $(P \leqslant 0.05)$.

Table 5 Phosphorus concentration, phosphorus content and shoot biomass of maize and faba bean under different phosphorus supply in the maize/faba bean intercropping system ${ }^{\text {a) }}$

\begin{tabular}{|c|c|c|c|c|c|c|c|c|}
\hline \multirow{2}{*}{\multicolumn{2}{|c|}{ Cropping system }} & \multirow{2}{*}{ Treatment } & \multicolumn{2}{|c|}{$\mathrm{P}$ concentration $\left(\mathrm{mg} \mathrm{g}^{-1}\right)$} & \multicolumn{2}{|c|}{$\mathrm{P}$ content $\left(\mathrm{mg} \mathrm{pot}^{-1}\right)$} & \multicolumn{2}{|c|}{ Shoot dry weight $\left(\mathrm{g} \mathrm{pot}^{-1}\right)$} \\
\hline & & & 20 & 150 & 20 & 150 & 20 & 150 \\
\hline \multirow{5}{*}{ Maize } & \multirow{2}{*}{ Mono } & $\mathrm{T} 222$ & $2.7 \pm 0.10 \mathrm{a}$ & $3.23 \pm 0.04 \mathrm{a}$ & $7.87 \pm 0.10 \mathrm{~b}$ & $16.35 \pm 1.01 \mathrm{~b}$ & $2.92 \pm 0.04 b$ & $5.07 \pm 0.31 b$ \\
\hline & & T149 & $2.72 \pm 0.13 a$ & $3.22 \pm 0.24 \mathrm{a}$ & $9.47 \pm 0.26 a$ & $17.31 \pm 1.56 b$ & $3.49 \pm 0.10 \mathrm{a}$ & $5.38 \pm 0.48 b$ \\
\hline & \multirow{2}{*}{ Inter } & $\mathrm{T} 222$ & $2.43 \pm 0.09 \mathrm{a}$ & $3.01 \pm 0.16 \mathrm{a}$ & $5.59 \pm 0.45 c$ & $18.25 \pm 0.82 b$ & $2.30 \pm 0.19 \mathrm{c}$ & $6.06 \pm 0.27 b$ \\
\hline & & T149 & $2.59 \pm 0.14 \mathrm{a}$ & $2.81 \pm 0.16 \mathrm{a}$ & $9.96 \pm 0.29 a$ & $25.64 \pm 1.42 \mathrm{a}$ & $3.84 \pm 0.11 \mathrm{a}$ & $9.13 \pm 0.51 \mathrm{a}$ \\
\hline & $\begin{array}{l}\text { Increase by } \\
\text { intercropping }(\%)\end{array}$ & $\mathrm{T} 222$ & -10 & -6.81 & -28.97 & 11.62 & -21.23 & 19.52 \\
\hline \multirow{5}{*}{ Faba bean } & Mono & $\mathrm{F}$ & $2.98 \pm 0.09 \mathrm{a}$ & $3.74 \pm 0.30 \mathrm{a}$ & $11.67 \pm 0.21 \mathrm{~b}$ & $19.03 \pm 0.84 \mathrm{c}$ & $3.92 \pm 0.07 \mathrm{~b}$ & $5.09 \pm 0.22 \mathrm{c}$ \\
\hline & \multirow{2}{*}{ Inter } & F/T222 & $2.82 \pm 0.20 \mathrm{a}$ & $4.00 \pm 0.20 \mathrm{a}$ & $15.19 \pm 0.90 \mathrm{a}$ & $27.25 \pm 1.45 \mathrm{a}$ & $5.69 \pm 0.16 \mathrm{a}$ & $6.81 \pm 0.36 a$ \\
\hline & & F/T149 & $2.82 \pm 0.34 \mathrm{a}$ & $3.96 \pm 0.32 \mathrm{a}$ & $12.55 \pm 0.55 b$ & $22.83 \pm 0.44 b$ & $4.45 \pm 0.20 \mathrm{~b}$ & $5.77 \pm 0.11 \mathrm{~b}$ \\
\hline & \multirow{2}{*}{$\begin{array}{l}\text { Increase by } \\
\text { intercropping }(\%)\end{array}$} & $\mathrm{T} 222$ & -5.36 & 6.95 & 30.16 & 43.19 & 45.15 & 33.79 \\
\hline & & T149 & -5.36 & 5.88 & 7.54 & 19.96 & 13.52 & 13.35 \\
\hline
\end{tabular}

a) Values are mean \pm SE of four replicates. Different letters indicate significant difference between genotypes within the same $P$ level $(P \leqslant 0.05)$. 
Table 6 Phosphorus concentration, content and shoot biomass of maize and wheat under different $\mathrm{P}$ supply in the maize/wheat intercropping system ${ }^{\text {a) }}$

\begin{tabular}{|c|c|c|c|c|c|c|c|c|}
\hline \multirow{2}{*}{\multicolumn{2}{|c|}{ Cropping system }} & \multirow{2}{*}{ Treatment } & \multicolumn{2}{|c|}{$\mathrm{P}$ concentration $\left(\mathrm{mg} \mathrm{g}^{-1}\right)$} & \multicolumn{2}{|c|}{ P content (mg) } & \multicolumn{2}{|c|}{ Shoot dry weight $(\mathrm{g})$} \\
\hline & & & 20 & 150 & 20 & 150 & 20 & 150 \\
\hline \multirow{5}{*}{ Maize } & \multirow{2}{*}{ Mono } & $\mathrm{T} 222$ & $2.47 \pm 0.09 \mathrm{a}$ & $3.53 \pm 0.06 \mathrm{a}$ & $1.57 \pm 0.13 b$ & $7.83 \pm 0.64 a$ & $0.63 \pm 0.03 b$ & $2.22 \pm 0.16 \mathrm{a}$ \\
\hline & & T149 & $2.35 \pm 0.17 \mathrm{ab}$ & $3.43 \pm 0.19 a$ & $2.03 \pm 0.06 \mathrm{a}$ & $7.79 \pm 0.99 a$ & $0.87 \pm 0.07 \mathrm{a}$ & $2.26 \pm 0.18 \mathrm{a}$ \\
\hline & \multirow{2}{*}{ Inter } & $\mathrm{T} 222$ & $1.99 \pm 0.14 b$ & $2.81 \pm 0.14 \mathrm{~b}$ & $0.75 \pm 0.06 c$ & $4.29 \pm 0.51 b$ & $0.38 \pm 0.05 \mathrm{c}$ & $1.52 \pm 0.13 b$ \\
\hline & & T149 & $2.09 \pm 0.08 \mathrm{ab}$ & $2.71 \pm 0.08 b$ & $1.40 \pm 0.11 \mathrm{~b}$ & $5.07 \pm 0.13 b$ & $0.67 \pm 0.06 b$ & $1.87 \pm 0.04 \mathrm{ab}$ \\
\hline & $\begin{array}{l}\text { Increase by } \\
\text { intercropping (\%) }\end{array}$ & $\mathrm{T} 222$ & -19.43 & -20.39 & -52.22 & -45.21 & -39.68 & -31.53 \\
\hline \multirow{5}{*}{ Wheat } & Mono & $\mathrm{W}$ & $3.28 \pm 0.08 \mathrm{a}$ & $6.37 \pm 0.14 b$ & $8.02 \pm 0.04 \mathrm{a}$ & $28.78 \pm 0.59 b$ & $2.45 \pm 0.07 a$ & $4.53 \pm 0.16 b$ \\
\hline & \multirow{2}{*}{ Inter } & $\mathrm{W} / \mathrm{T} 222$ & $3.58 \pm 0.10 \mathrm{a}$ & $6.63 \pm 0.04 \mathrm{ab}$ & $8.48 \pm 0.76 a$ & $37.35 \pm 0.61 \mathrm{a}$ & $2.36 \pm 0.16 \mathrm{a}$ & $5.63 \pm 0.10 \mathrm{a}$ \\
\hline & & W/T149 & $3.57 \pm 0.11 \mathrm{a}$ & $6.86 \pm 0.22 \mathrm{a}$ & $8.84 \pm 0.72 \mathrm{a}$ & $38.03 \pm 2.08 \mathrm{a}$ & $2.48 \pm 0.22 \mathrm{a}$ & $5.54 \pm 0.26 \mathrm{a}$ \\
\hline & \multirow{2}{*}{$\begin{array}{l}\text { Increase by } \\
\text { intercropping (\%) }\end{array}$} & $\mathrm{T} 222$ & 9.14 & 4.08 & 5.73 & 29.77 & -3.67 & 24.28 \\
\hline & & T149 & 8.84 & 7.69 & 10.22 & 32.14 & 1.22 & 22.29 \\
\hline
\end{tabular}

a) Values are mean \pm SE of four replicates. Different letters indicate significant difference between genotypes within the same $P$ level $(P \leqslant 0.05)$.

intercropped with T222 (by 45\%) than with T149 (by 14\%) (Tables 1 and 5). The total biomass production of the intercropping system was greater when faba bean was intercropped with T149 than with T222 under high P, but not under low P supply (Figure 1).

When intercropped with wheat, the shoot dry weight in T222 was decreased by $40 \%$ and that of T149 was decreased by $23 \%$, compared with those in the monocropping system (Tables 3 and 6). Under low P, intercropping with maize did not affect wheat shoot biomass. Under high $\mathrm{P}$ supply, however, the shoot biomass of wheat was increased
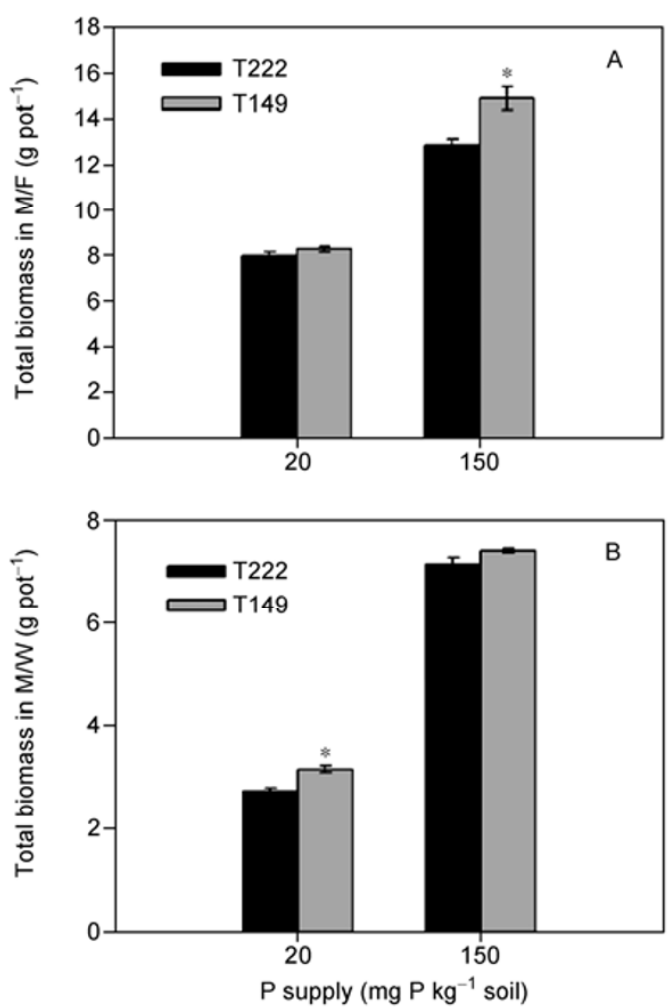

Figure 1 Total biomass of maize/faba bean (M/F, A) and maize/wheat $(\mathrm{M} / \mathrm{W}, \mathrm{B})$ intercropping systems. Values are mean $\pm \mathrm{SD}$ of three replicates. Asterisks indicate significant differences between means at $P \leqslant 0.05$. by intercropping with maize. The intercropping effect was similar between the two maize genotypes (24\% increase in shoot biomass with T222 and 22\% with T149). The total biomass production of the intercropping system was higher when wheat was intercropped with T149 than with T222 under low $\mathrm{P}$ but not under high $\mathrm{P}$ supply (Figure 1).

\subsection{Comparison of $P$ nutrient competitive ratio (CR) between the two maize genotypes}

When intercropped with faba bean, the CR of T149 relative to faba bean was significantly higher than that of T222, irrespective of the P level (Figure 2). The P nutrient CR of maize T149 was higher than 1, whereas that of T222 was lower than 1, which suggested that T149 had a better P acquisition ability than T222. In the maize/wheat intercropping system, the $\mathrm{P}$ nutrient CRs of maize relative to wheat were lower than 1 for both maize genotypes, which suggested maize had a lower P acquisition ability than wheat. Nevertheless, the CR of maize T149 relative to wheat was significantly higher than that of T222 at the low P level, which indicated that $\mathrm{T} 149$ had a higher ability for P acquisition than T222 under low-P stress (Figure 2).

\section{Discussion}

In a maize/faba bean intercropping system, maize and faba bean can both benefit, at least partly, from the belowground interaction; that is, the root growth of both species is compatible and they use different $\mathrm{P}$ resources [17,27,32]. Faba bean shows a stronger capability to acidify the rhizosphere, which helps maize plants to obtain higher levels of P [19]. Therefore, it is expected that increasing maize root growth may contribute to higher maize productivity without having a negative effect on faba bean growth. Indeed, under high $\mathrm{P}$ supply, shoot growth and $\mathrm{P}$ accumulation of the larger-rooted T149 were dramatically increased by intercropping, compared with those of the smaller-rooted T222. 

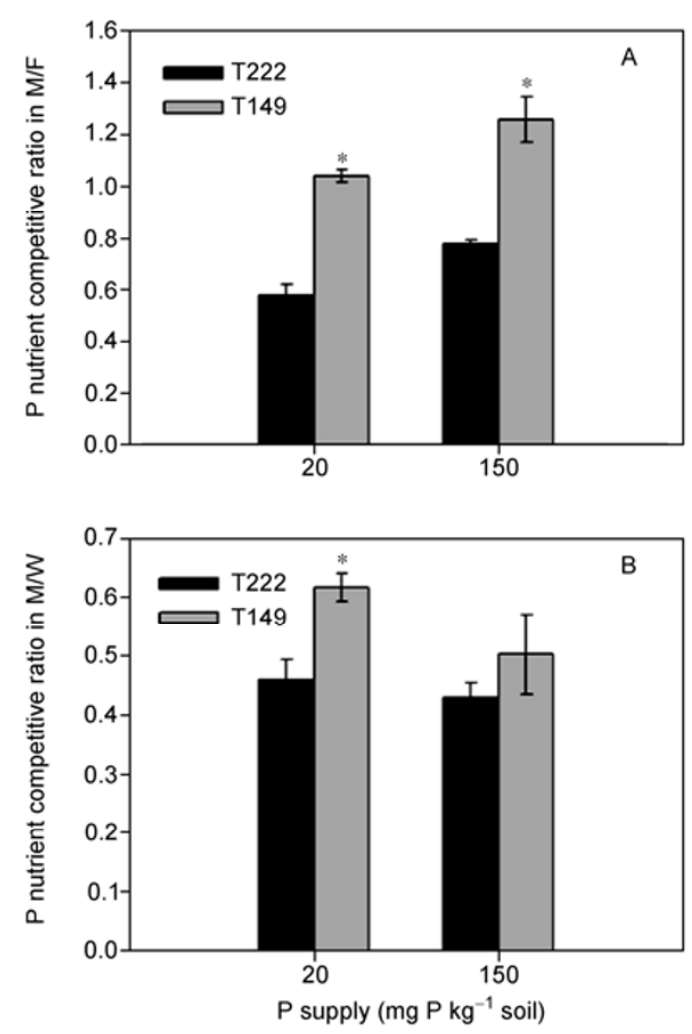

Figure 2 Phosphorus nutrient competitive ratio of maize T222 and T149 relative to faba bean or wheat in maize/faba bean $(\mathrm{M} / \mathrm{F}, \mathrm{A})$ and maize/wheat $(\mathrm{M} / \mathrm{W}, \mathrm{B})$ intercropping systems. Values are mean $\pm \mathrm{SD}$ of three replicates. Asterisks indicate significant differences between means at $P \leqslant 0.05$.

Therefore, the larger root system in T149 enabled it to make better use of the soil P solubilized by faba bean. As a result, the total biomass of the intercropping system was greater when faba bean was intercropped with the larger-rooted T149 than with the smaller-rooted T222 (Figure 1). However, the mutual beneficial effect in the maize/faba bean system appeared to be affected by the $\mathrm{P}$ availability in the soil. When the P supply was inadequate, there was competition between the two species for the $\mathrm{P}$ resource. Gardner et al. [33] reported that the shoot biomass of maize intercropped with lupins increased alongside a reduction in growth of the intercropped lupins at low P supply. Jackman and Mouat [34] reported that white clover required much more $\mathrm{P}$ to produce the same quantity of dry matter when intercropped with Agrostis tenuis than when grown alone. In the present study, there was also competition for the limited $\mathrm{P}$ resource in the maize/faba bean system. This was confirmed by the decrease in shoot $\mathrm{P}$ concentration in both maize and faba bean in the intercropping system, compared with the monocropping systems (Table 5). The CR is an assessment of the competitive ability of crops [30,31]. In the maize/faba bean intercropping system, the $\mathrm{P}$ nutrient $\mathrm{CR}$ of T149 relative to faba bean in the maize/faba bean intercropping system was higher than 1, whereas the CR of T222 was lower than 1 , which indicated that the competitive ability of T149 was greater than that of T222 (Figure 2). Under P-limiting conditions, the high competitiveness of the larger-rooted T149 enabled it to obtain greater benefit from faba bean, allowing it to take up more $\mathrm{P}$ and produce greater shoot biomass than T222. Conversely, although faba bean derived benefits from intercropping with either maize genotype, it benefitted more from the interaction with the smaller-rooted T222 because there was less competition for $\mathrm{P}$ resources. Compared with faba bean/T149, P accumulation and biomass were higher in faba bean, but lower in maize in the faba bean/T222 system. As a result, the total P uptake and biomass production was similar between the faba bean/T149 and faba bean/T222 systems. These results suggested that when the $\mathrm{P}$ resource is deficient, increasing root size of maize is limited for improving the productivity of the intercropping systems, and a P-efficient faba bean cultivar may be more useful. Peng [35] reported similar results to those of the present study in a system in which "Lincan 5" was intercropped with maize. In addition, another P-efficient faba bean cultivar, "Yundou 324", increased the total biomass of the intercropping system under P deficiency.

Plant growth also can be affected negatively by intercropping. In cassava/groundnut intercropping systems, cassava accumulated approximately $96 \%-99 \%$ of the total ${ }^{32} \mathrm{P}$ in the system, whereas groundnut absorbed only negligible quantities of ${ }^{32} \mathrm{P}$ from the cassava root zone [36]. Casper and Jackson [37] reported that belowground competitive ability was correlated with attributes such as density, surface area, and plasticity of root growth, all of which play roles in nutrient uptake. Previous research has shown that maize is inhibited by intercropped wheat $[15,17,22]$. In the present study, the CR of both maize genotypes lower than 1 , indicating that maize was a weaker competitor than wheat. Therefore, the biomass and $\mathrm{P}$ uptake in both maize genotypes were markedly decreased by intercropping, regardless of $\mathrm{P}$ supply. Li et al. [17] showed that the reduction in maize growth was at least partly because of the greater belowground competitive ability of wheat. Wheat roots extended below the maize rows, and the root length density of maize was reduced when intercropped with wheat. $P$ transport to the root surface is mainly governed by diffusion due to because of its low mobility in soil [38]. Therefore, the size of the root system is one of most important factors determining P uptake. The competitive ability of T149 was greater than that of T222 under low-P conditions, as indicated by the $\mathrm{P}$ nutrient CRs. Compared with the smaller-rooted T222, the larger-rooted T149 suffered less from intercropping (Table 6). Nevertheless, the higher competitiveness of T149 than T222 did not affect the growth of the intercropped wheat. As a result, the total biomass of the wheat/maize intercropping system was higher in the wheat/T149 system than in the wheat/T222 system under low-P supply. These data suggested that, under P-limited 
conditions, increasing maize root size could improve maize growth without negatively affecting wheat, and increase the productivity of the intercropping system. Under high $\mathrm{P}$ supply, the inhibition of maize root and shoot growth by intercropped wheat was less severe (Tables 4 and 6). Compared with T222, shoot growth of T149 was less inhibited by intercropped wheat. Thus, wheat obtained less benefit from intercropping with T149 than with T222. Therefore, the productivity of the wheat/T149 and wheat/T222 systems was similar under high-P conditions. Li et al. [22] suggested that interspecific competition in cereal-cereal intercropping systems could be alleviated by increasing nutrient application, and that the increasing yield advantage of intercropping was related to the competitive ability of the crops, the soil fertility, and fertilizer application.

In conclusion, this study demonstrated that the genetic improvement of maize root size could enhance maize growth and its competitive ability for $\mathrm{P}$ resources in maize/ faba bean and maize/wheat intercropping systems. These results showed that the productivity of the maize/faba bean intercropping system was improved under adequate $\mathrm{P}$ supply and the productivity of the maize/wheat intercropping system was improved when P supply was limited.

This work was supported by the National Natural Science Foundation of China (Grant Nos. 31121062 and 31071852), the National Basic Research Program of China (Grant No. 2009CB11860), and the Special Fund for the Agricultural Profession (Grant No. 201103003). We are grateful to Dr. Tang HongLiang for his valuable suggestions on data analysis.

1 Raghothama K G. Phosphate acquisition. Annu Rev Plant Biol, 1999, 50: 665-693

2 Batjes N H. A world dataset of derived soil properties by FAOUNESCO soil unit for global modelling. Soil Use Manage, 1997, 13: 9-16

3 Vance C P, Uhde-Stone C, Allan D L. Phosphorus acquisition and use: critical adaptations by plants for securing a nonrenewable resource. New Phytol, 2003, 157: 423-447

4 Liu Y, Mi G H, Chen F J, et al. Rhizosphere effect and root growth of two maize (Zea mays L.) genotypes with contrasting $\mathrm{P}$ efficiency at low P availability. Plant Sci, 2004, 167: 217-223

5 Zhu J M, Lynch J P. The contribution of lateral rooting to phosphorus acquisition efficiency in maize (Zea mays) seedlings. Funct Plant Biol, 2004, 31: 949-958

6 Lynch J P, Brown K M. Root strategies for phosphorus acquisition. In: The Ecophysiology of Plant-Phosphorus Interactions. New York: Springer, 2008. 83-116

7 Ramaekers L, Remans R, Rao I M, et al. Strategies for improving phosphorus acquisition efficiency of crop plants. Field Crop Res, 2010, 117: 169-176

8 Lambers H, Shane M W, Cramer M D, et al. Root structure and functioning for efficient acquisition of phosphorus: matching morphological and physiological traits. Ann Bot, 2006, 98: 693-713

9 Zhang H W, Huang Y, Ye X S, et al. Genotypic variation in phosphorus acquisition from sparingly soluble $\mathrm{P}$ sources is related to root morphology and root exudates in brassica napus. Sci China Life Sci, 2011, 54: 1134-1142

10 Gomez A A, Gomez K A. Multiple cropping in the humid tropics of Asia. International Development Research Centre, 1983

11 Harris D, Natarajan M, Willey R. Physiological basis for yield advantage in a sorghum/groundnut intercrop exposed to drought. 1.
Dry-matter production, yield, and light interception. Field Crop Res, 1987, 17: 259-272

12 Zhang F S, Li L. Using competitive and facilitative interactions in intercropping systems enhances crop productivity and nutrient-use efficiency. Plant Soil, 2003, 248: 305-312

13 Xu B C, Li F M, Shan L. Switchgrass and milkvetch intercropping under 2:1 row-replacement in semiarid region, northwest China: aboveground biomass and water use efficiency. Eur J Agron, 2008, 28: 485-492

14 Li L, Li S M, Sun J H, et al. Diversity enhances agricultural productivity via rhizosphere phosphorus facilitation on phosphorus-deficient soils. Proc Natl Acad Sci, 2007, 104: 11192-11196

15 Li L, Sun J H, Zhang F S, et al. Wheat/maize or wheat/soybean strip intercropping: I. Yield advantage and interspecific interactions on nutrients. Field Crop Res, 2001, 71: 123-137

16 Li L, Zhang F S, Li X L, et al. Interspecific facilitation of nutrient uptake by intercropped maize and faba bean. Nutr Cycl Agroecosys, 2003, 65: 61-71

17 Li L, Sun J H, Zhang F S, et al. Root distribution and interactions between intercropped species. Oecologia, 2006, 147: 280-290

18 Dauro D, Mohamed-Saleem M A. Shoot and root interactions in intercropped wheat and clover. Trop Agr, 1995, 72: 170-172

19 Zhou L L, Cao J, Zhang F S, et al. Rhizosphere acidification of faba bean, soybean and maize. Sci Total Environ, 2009, 407: 4356-4362

20 Li H G, Shen J B, Zhang F S, et al. Phosphorus uptake and rhizosphere properties of intercropped and monocropped maize, faba bean, and white lupin in acidic soil. Biol Fert Soils, 2010, 46: 79-91

21 Li L, Sun J H, Zhang F S, et al. Wheat/maize or wheat/soybean strip intercropping: II. Recovery or compensation of maize and soybean after wheat harvesting. Field Crop Res, 2001, 71: 173-181

22 Li Q Z, Sun J H, Wei X J, et al. Overyielding and interspecific interactions mediated by nitrogen fertilization in strip intercropping of maize with faba bean, wheat and barley. Plant Soil, 2011, 339: 147-161

23 Li C J. Crop $\mathrm{N}$ use and root exudates role in root morphology changes in different intercropping combination (in Chinese). Dissertation for Doctoral Degree. Beijing: China Agricultural University, 2010

24 Wang D M, Marschner P, Solaiman Z, et al. Growth, P uptake and rhizosphere properties of intercropped wheat and chickpea in soil amended with iron phosphate or phytate. Soil Biol Biochem, 2007, 39: 249-256

25 Wang Y, Mi G H, Chen F J, et al. Response of root morphology to nitrate supply and its contribution to nitrogen accumulation in maize. J Plant Nutr, 2004, 27: 2189-2202

26 Zhang Y K. Genetic improvement of root growth contributes to efficient phosphorus acquisition in maize (Zea mays L.) (in Chinese). Dissertation for Doctoral Degree. Beijing: China Agricultural University, 2012

27 Li L, Yang S C, Li X L, et al. Interspecific complementary and competitive interactions between intercropped maize and faba bean. Plant Soil, 1999, 212: 105-114

28 Fan F L, Zhang F S, Song Y N, et al. Nitrogen fixation of faba bean (Vicia faba L.) interacting with a non-legume in two contrasting intercropping systems. Plant Soil, 2006, 283: 275-286

29 Murphy J, Riley J P. A modified single solution method for the determination of phosphate in natural waters. Anal Chim Acta, 1962, 27: 31-36

30 Willey R W, Rao M R. A competitive ratio for quantifying competition between intercrops. Exp Agr, 1980, 16: 117-125

31 Wahla I H, Ahmad R, Ehsanullah A A, et al. Competitive functions of components crops in some barley based intercropping systems. Int J Agric Biol, 2009, 11: 69-72

32 Song Y N, Zhang F S, Marschner P, et al. Effect of intercropping on crop yield and chemical and microbiological properties in rhizosphere of wheat (Triticum aestivum L.), maize (Zea mays L.), and faba bean (Vicia faba L.). Biol Fert Soils, 2007, 43: 565-574

33 Gardner W K, Boundy K A. The acquisition of phosphorus by Lupinus albus L. IV. The effect of interplanting wheat and white lupin on the growth and mineral composition of the two species. Plant Soil, 1983, 70: 391-402 
34 Jackman R H, Mouat M C H. The effect of browntop (Agrostis tennis (Sibth.)) and increasing phosphorus deficiency on the growth of white clover (Trifolium repens L.). In: Proceedings of the 11th International Grassland Congress, Surfers Paradise, 1970. 354

35 Peng H Y. Phosphorus utilization and effects of faba bean cultivars on intercropped maize (in Chinese). Dissertation for Master's Degree. Beijing: China Agricultural University, 2012
36 Ashokan P K, Wahid P A, Sreedharan C. Relative uptake of ${ }^{32} \mathrm{P}$ by cassava, banana, elephant foot yam and groundnut in intercropping systems. Plant Soil, 1988, 109: 23-30

37 Casper B B, Jackson R B. Plant competition underground. Annu Rev Ecol Syst, 1997, 545-570

38 Barber S A. Soil nutrient bioavailability: A mechanistic approach. New York: John Wiley \& Sons Inc, 1995

Open Access This article is distributed under the terms of the Creative Commons Attribution License which permits any use, distribution, and reproduction in any medium, provided the original author(s) and source are credited. 